\title{
STRENGTH-WEAKNESS-OPPROTUNITY-THREAT (SWOT) ANALYSIS TO ENHANCE PRODUCTIVITY OF BATIK INDUSTRY CENTRE IN EAST JAVA PROVINCE INDONESIA
}

\author{
Ika Atsari Dewi ${ }^{*}$, Susinggih Wijana ${ }^{1}$, M. Andhy Nurmansyah ${ }^{2}$, Romy Setiawan $^{3}$, \\ Wendra G. Rohmah ${ }^{1}$, Nur Lailatul Rahmah ${ }^{1}$, Rheysa Permata Sari ${ }^{1}$ \\ ${ }^{1}$ Agro-industrial Technology Department, Universitas Brawijaya, Malang, Indonesia \\ ${ }^{2}$ English Literature Department, Universitas Brawijaya, Malang, Indonesia \\ ${ }^{3}$ Fine Arts Department, Universitas Brawijaya, Malang, Indonesia \\ *Corresponding Author: ikaatsaridewi@ub.ac.id
}

\begin{abstract}
It is acknowledged that the struggle faced by the batik industry, particularly in the Province of East Java, dealing with growth challenges caused by several factors: less attractive design, the conventional use of manual handling, and less governmental-institutional support. The purpose of this study is to analyze the performance of centers of Batik industry in Sampang, Trenggalek and Tuban Regencies highlighting their related-production quality and quantity. The location selection of batik production centers is based on coordination with Department of Industry and Trade in each area. Data is collected through surveys and interviews. This study concludes several things. There are six production system elements analyzed in this research included technology (production capacity of batik), funding, raw material, human resources, marketing, and pattern design.
\end{abstract}

Keywords: batik pattern, micro small medium entreprises, productivity

\section{INTRODUCTION}

Batik is one of the original Indonesian technique in cloth dyeing, using wax to cover specific patterns so they will not receive the colour. Batik is not only an art, but also a craft, which become more popular as one of the creative industry sectors. UNESCO inscribed Indonesian Batik on the Representative List of the Intangible Cultural Heritage of Humanity in 2009 (Bungin, 2005). In the present the needs of market and production of batik are very high not only in the form of cloth, but also various crafts.

The development of batik craft centers in East Java has not been as encouraging as in Central Java Province. Batik craft centers in East Java include Madura, Malang, Jombang, Tulungagung and Kediri Regencies. Among these areas, the region of Madura experiences rapid development with its center in Sampang, Pamekasan and Sumenep Subdistrict. The various centers of East Java batik nowadays have been trying to develop designs with various innovative batik products, but the results achieved have not been maximized.

The fundamental weakness faced by handicraft centers in East Java is the lack of development of batik design and still the traditional production technology used. Both of these have an impact on low product competitiveness due to the small production capacity and the sluggish innovation of existing batik patterns. Apart from the technological aspects of the institutional aspects involved in the development of batik SMEs are also not developed as well as in the region of Central Java. Institutional role should be able to accelerate the ability of batik artisans in improvisation of design and technology adoption, improvement of production efficiency, expansion of marketing network and efficiency of promotion media for all artisans in batik craft area. The aim of this study was to find out the qualitative Strength-Weakness-Opportunity-Threat (SWOT) analysis of some batik industry centres in East Java Province, Indonesia.

\section{METHOD}

This research is limited to evaluation and planning of solution strategy in the scope of component of batik production system such as Technology (Low production capacity), Capital (Low capital interest), Raw material (Low availability and High price), Human resource (Lack of skillful batik-dyeing process), Marketing (Weak partnership system), and Design (Motive predominantly by natural resources, cultural motif has not yet emerging).

Research is also limited to recommendations to companies not until implementation. This research uses qualitative method with Strength-Weakness-Opportunity-Threat (SWOT) analysis and quantitative calculation with scoring method. There are nine owners of batik SMEs in Sampang, Trenggalek and Tuban Regencies as rrespondents. This 
study uses three criterias: cost affordability, ease of implementation, and effectiveness of resource use. Twenty eight variables are used, which consists of a list of corporate strengths, weaknesses, opportunities, and threats (SWOT) analysis results. The research variables can be seen in Table 1 .

The sampling techniques used was purposive sampling, a data collection with a technique of sampling collection from data resources considered mastering material expected so that can ease the research process (Sugiyono, 2014). Data collection methods used was semi-structured interview and observation. Observation is a data collection method that can be used to collect the data which can be observed by the researcher (Bungin, 2005).

Through the researcher's consideration, respondents chose to help this research are those having Small and Medium Enterprise (widely known as UKM in Bahasa) in Batik production to get information on internal and external environment condition of the company. Another consideration to decide the point of the main weakness, strength, opportunity, and threat until the solution alternative determination was done with a discussion between researcher and respondents.

Table 1: SWOT Analysis to the Components Of Batik Production System

\begin{tabular}{|c|c|c|c|}
\hline No & $\begin{array}{c}\text { Production } \\
\text { System Element }\end{array}$ & $\begin{array}{l}\text { Element } \\
\text { SWOT }\end{array}$ & Problem Statement \\
\hline \multirow{4}{*}{1.} & \multirow{4}{*}{$\begin{array}{l}\text { Technology (Low } \\
\text { capacity of batik } \\
\text { production) }\end{array}$} & Strength & $\begin{array}{l}\text { - Batik Tulis (hand-drawn batik) has been longer mastered by the } \\
\text { craftsmen in East Java. } \\
\text { - Batik Tulis, especially those colored with natural color is } \\
\text { relatively more expensive than printed batik. }\end{array}$ \\
\hline & & Weakness & $\begin{array}{l}\text { - The production capacity of batik tulis is low since depending on } \\
\text { the women labor's skill. } \\
\text { - Natural color for batik tulis is hard to be widely produced since } \\
\text { the lack of availability of raw material. }\end{array}$ \\
\hline & & Opportunity & $\begin{array}{l}\text { - Production development into the semi-printed technology with a } \\
\text { bigger capacity through appropriate technology introduction of } \\
\text { printed-drawn and Sablon-drawn combination. }\end{array}$ \\
\hline & & Challenges & $\begin{array}{l}\text { - Not all UKM in Batik production based in a regional area has a } \\
\text { skill on printed and Sablon, for that matter, education and } \\
\text { training on it are required. } \\
\text { - Production technology changes into the semi-printed technology } \\
\text { must be offset by market development effort so that all batik } \\
\text { products can be absorbed. }\end{array}$ \\
\hline \multirow{4}{*}{2.} & \multirow{4}{*}{$\begin{array}{l}\text { Capitalization } \\
\text { (Low-interest } \\
\text { capital is } \\
\text { plentiful, UKM is } \\
\text { not able to } \\
\text { absorb) }\end{array}$} & Strength & $\begin{array}{l}\text { - There are many capitalizations offering debt for equity with low- } \\
\text { interest credit for UKM development. }\end{array}$ \\
\hline & & Weakness & $\begin{array}{l}\text { - There are no many UKMs in batik production which is able to } \\
\text { access credit debt for equity with low interest. }\end{array}$ \\
\hline & & Opportunity & $\begin{array}{l}\text { - Maximization of the number of UKM which is able to access } \\
\text { capital credit with low interest. }\end{array}$ \\
\hline & & Challenges & $\begin{array}{l}\text { - The ability of production management and marketing of UKM } \\
\text { engaged in batik production is inadequate, in order to enhance } \\
\text { the capability, long-terms empowerment (structured-training and } \\
\text { an additional account) are still required. }\end{array}$ \\
\hline \multirow[t]{4}{*}{3.} & \multirow{4}{*}{$\begin{array}{l}\text { Raw material } \\
\text { (low availability } \\
\text { and high price) }\end{array}$} & Strength & $\begin{array}{l}\text { - The number of UKM in batik production that has been existed } \\
\text { and its possibility of development in the future. }\end{array}$ \\
\hline & & Weakness & $\begin{array}{l}\text { - The lack of facility provided by government or private sector to } \\
\text { build a cooperative of facility and infrastructure for batik } \\
\text { development which is able to provide an affordable batik } \\
\text { production needs. }\end{array}$ \\
\hline & & Opportunity & $\begin{array}{l}\text { - Establishing economic entity of raw material and additional } \\
\text { material procurement for batik production. }\end{array}$ \\
\hline & & Challenges & $\begin{array}{l}\text { - In order to establish a cooperative providing facility and } \\
\text { infrastructure for batik development, it needs a commitment } \\
\text { between related stakeholder (departments and batik craftsman } \\
\text { association), funding planning, and the human resources ability } \\
\text { to manage cooperative. }\end{array}$ \\
\hline 4. & $\begin{array}{l}\text { Human Resource } \\
\text { (skilled-batik }\end{array}$ & Strength & $\begin{array}{l}\text { - A skill to produce batik tulis has been mastered by an old } \\
\text { generation which will be easy to be taught to the younger }\end{array}$ \\
\hline
\end{tabular}




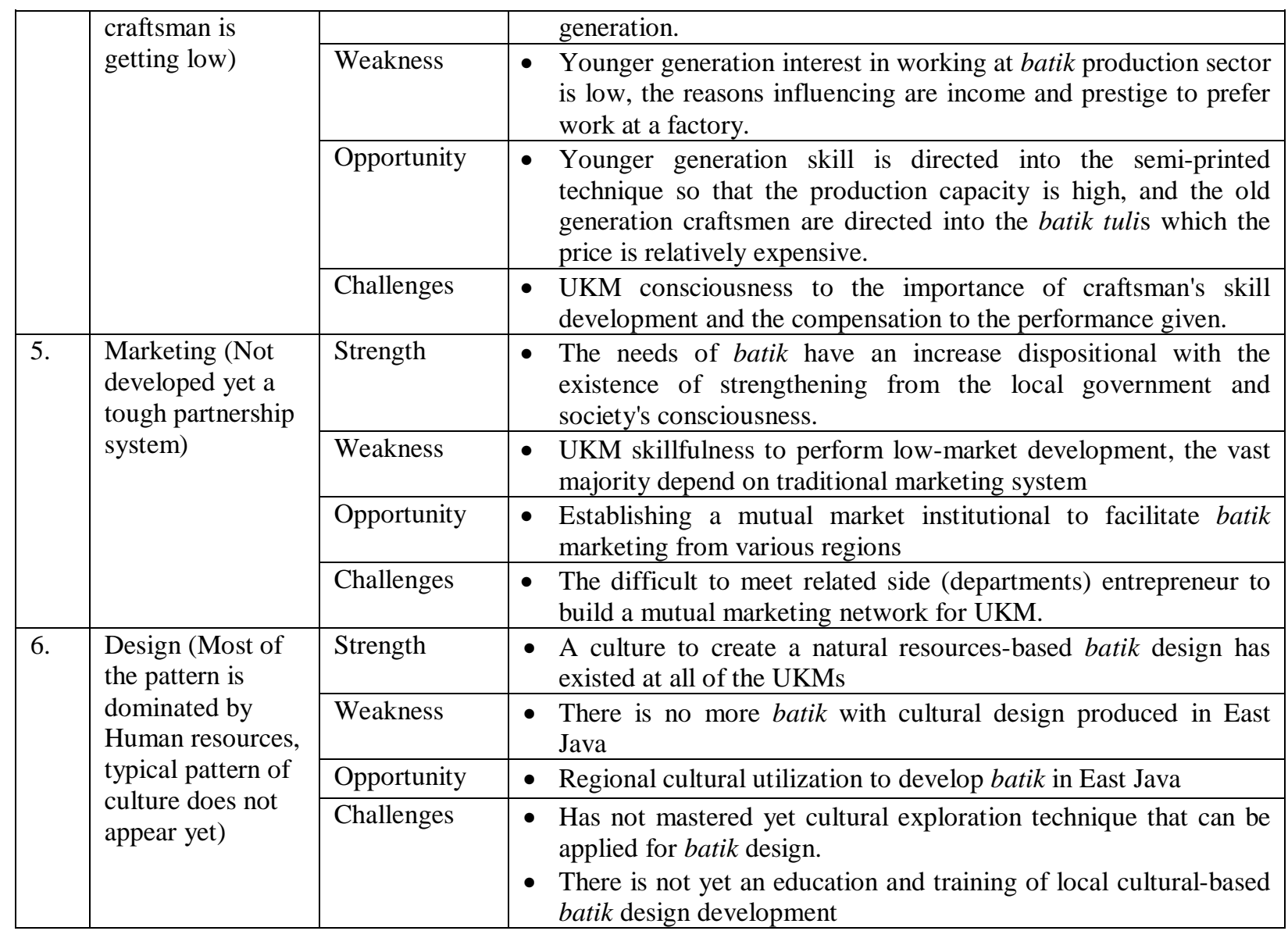

\subsection{SMEs Condition Analysis and Solution Strategy Planning with SWOT Analysis}

Through consideration of researchers and respondents, the analysis of the condition of SMEs Batik using SWOT both from the internal and external aspects of the company with qualitative way will produce research variables. Formulation of alternative solution also obtained from qualitative method that is with discussion between researcher with respondent and consider research variable. Hence, the alternative formulation of the solution will be divided into four categories containing of combinations of two aspects: SO (Strength-Opportunity), ST (Strength-Threat), WO (Weakness-Opportunity), and WT (Weakness-Threat). Explanation of the comparison matrix is among others (Rangkuti, 2006):

a. SO strategy is based on the company's way of thinking, by utilizing all the power to seize and take advantage of opportunities as much as possible

b. Strategy ST is made by using the strength of the company to overcome the threat.

c. WO strategy is applied based on the utilization of existing opportunities by minimizing the weaknesses owned by the company.

d. WT strategy is based on activities that are defensive and try to minimize the weaknesses of the company and avoid threats.

\subsection{Determining Alternative Solutions with Scoring Solutions}

Alternative solutions analyzed using scoring is an alternative solution that has been formulated with consideration of internal and external factors of the company. Scoring methods are used to get the main priority of alternative solutions that must be done for the most optimal improvement. The assessment of alternative solutions is based on the criteria that influence the selection of those alternatives. The first scoring is done by assigning a weighted value to each of the criteria. The weighted value scale is given in the range of 0 to 1 , with the total weight of all criteria is 1. Both provide a ranking rating against the alternative solutions that have been formulated. The rated scores for ratings of 1 to 5 with 1 are the worst and 5 is the best value. The results obtained the average total score of the multiplication of weights and the ranking of each alternative solution. The result of the highest score is then become an alternative solution with the top priority.

\section{RESULTS AND DISCUSSION}

\subsection{Result of Alternative Solution Formulation with SWOT Analysis}

Referring to the internal and external factors of the company, the SWOT analysis gives the alternative consideration of the solution not from the positive side of the company but also from the negative side of the company such as 
weaknesses and threats so that alternative solutions will become more in line with the company's ability to be realized. The results of alternative formulated solutions can be seen in Table 2 below.

Table 2: Solution Alternative With SWOT Matrices

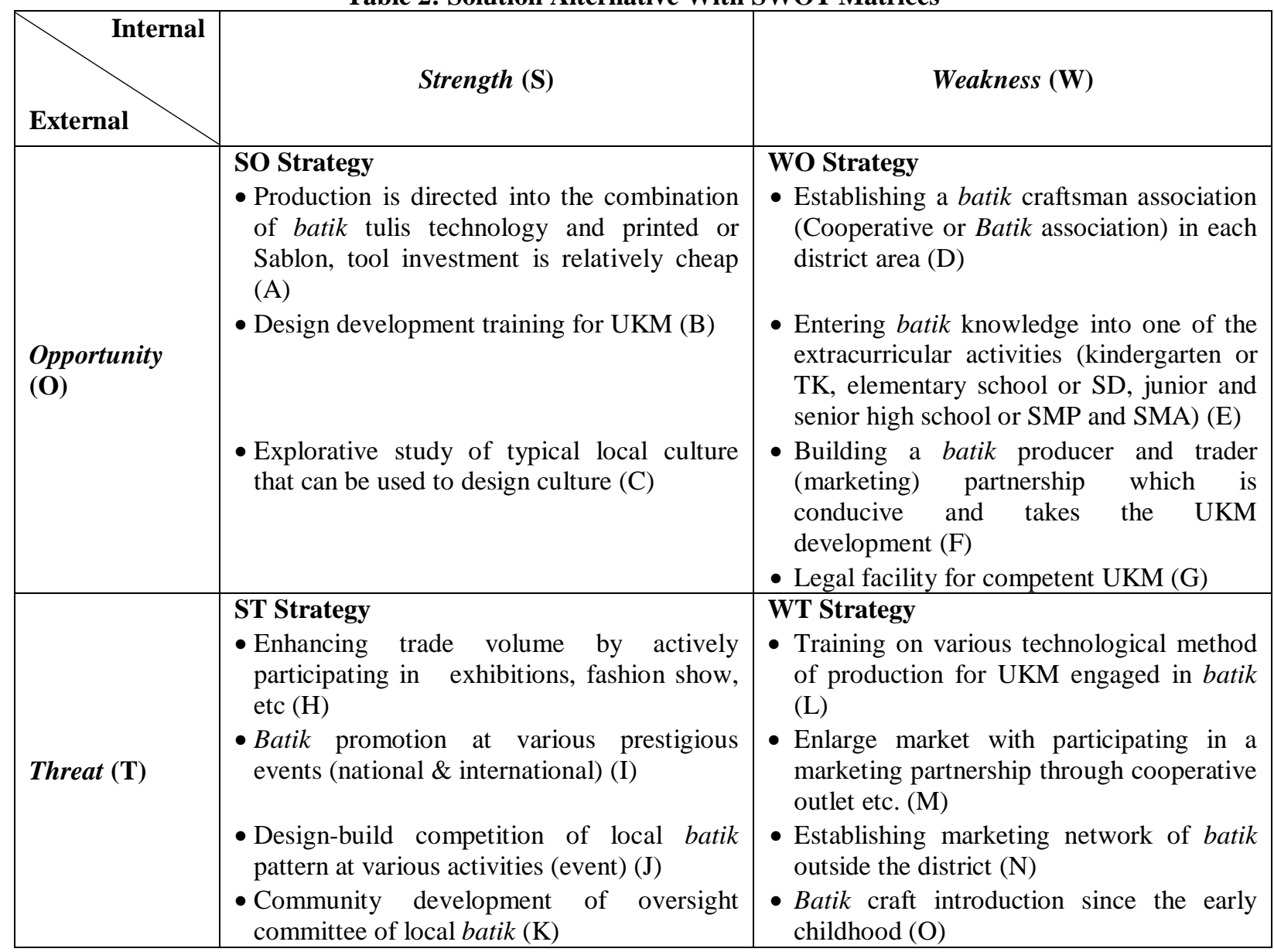

Fifteen alternative solutions are formulated on the basis of root causes such as low-cost traditional batik production because of relying on human skills, stamp techniques and high-speed printing speeds, but selling low-price products, not dominating the market (relatively small product demand), most craftsmen rely on sales system with cash payment, the absence of workshop materials raw materials capable of serving the quantity and continuity high, and low prices, the job requires skill and perseverance that is meticulous, low income workers, image of batik work for younger generation decreased, business between SMEs and traders (distributors), batik motifs obtained by selftaught and modeled, mostly patterned SDA, not many local cultural motives, depending on the trend / model real needs market, and very few batik motifs that get Patent. The root of the problem is used as a reference in the formulation of alternative solutions so that the alternatives formed can minimize the existing problems and even eliminate them.

\subsection{Result of Calculation of Alternative Preference Solution with Scoring Method}

Alternative solutions that have been formulated fifteen then assessed the total score of each to see how big the priority level in each alternative solution. The alternative assessment of this solution also takes into consideration the criterion value used as a consideration in running the alternative solution. The results of the average score calculation can be seen in Table 3 .

Table 3: Priority Scale Calculation of Solution Alternatives with Scoring Method

\begin{tabular}{|c|c|c|c|c|c|c|c|c|c|c|c|c|c|c|c|c|}
\hline \multirow[b]{2}{*}{ Criteria } & \multirow[b]{2}{*}{ Weight } & \multicolumn{15}{|c|}{ Solution Alternatives Types } \\
\hline & & $\mathbf{A}$ & B & $\mathbf{C}$ & D & $\mathbf{E}$ & $\mathbf{F}$ & $\mathbf{G}$ & H & I & $\mathbf{J}$ & $\mathbf{K}$ & $\mathbf{L}$ & $\mathbf{M}$ & $\mathbf{N}$ & $\mathbf{O}$ \\
\hline $\begin{array}{l}\text { Ease of } \\
\text { Implementation }\end{array}$ & 0,2 & 5 & 5 & 4 & 4 & 5 & 3 & 3 & 4 & 4 & 2 & 3 & 4 & 4 & 3 & 3 \\
\hline
\end{tabular}




\begin{tabular}{|l|c|c|c|c|c|c|c|c|c|c|c|c|c|c|c|c|}
\hline Affordable Cost & 0,5 & 4 & 3 & 5 & 5 & 4 & 2 & 4 & 3 & 3 & 3 & 4 & 5 & 3 & 3 & 5 \\
\hline $\begin{array}{l}\text { Effectivity } \\
\text { Resources } \\
\text { Utilization }\end{array}$ & 0,3 & 5 & 4 & 4 & 3 & 4 & 3 & 4 & 5 & 5 & 3 & 5 & 3 & 4 & 3 & 2 \\
\hline Total Weight & $\mathbf{1}$ & $\mathbf{4 , 5}$ & $\mathbf{3 , 7}$ & $\mathbf{4 , 5}$ & $\mathbf{4 , 2}$ & $\mathbf{4 , 2}$ & $\mathbf{2 , 2}$ & $\mathbf{3 , 8}$ & $\mathbf{3 , 8}$ & $\mathbf{3 , 8}$ & $\mathbf{2 , 5}$ & $\mathbf{4 , 2}$ & $\mathbf{4 , 2}$ & $\mathbf{3 , 5}$ & $\mathbf{3 , 0}$ & $\mathbf{3 ,}$ \\
\hline Priority Rank & & $\mathbf{1}$ & $\mathbf{4}$ & $\mathbf{1}$ & $\mathbf{2}$ & $\mathbf{2}$ & $\mathbf{8}$ & $\mathbf{3}$ & $\mathbf{3}$ & $\mathbf{3}$ & $\mathbf{7}$ & $\mathbf{2}$ & $\mathbf{2}$ & $\mathbf{5}$ & $\mathbf{6}$ & $\mathbf{4}$ \\
\hline
\end{tabular}

The total weight value for each criterion is one. The values of each criterion include the ease of implementation of 0.2 ; affordability of the cost of 0.5 and the effectiveness of the use of resources 0.3 . Criteria with the greatest weight is the affordability of costs, it is because cost is a very important factor for the company because it must be through consideration and adjustment with the ability of the company (Iwantono, 2011). The solution priority scale of problems in Batik SMEs centre development can be seen in Table 4.

Table 4: Priority Scale Of Problem Solution In A Center Of UKM Engaged In Batik Development

\begin{tabular}{|c|c|c|c|c|}
\hline No & Solution Alternative & Symbol & Scale & Rationalization \\
\hline 1. & $\begin{array}{l}\text { Product is directed into the } \\
\text { combination of batik tulis } \\
\text { technology and printing, tool } \\
\text { investment is relatively cheap }\end{array}$ & A & 1 & $\begin{array}{l}\text { - Integrated technology will enhance production } \\
\text { capacity to decrease product price }\end{array}$ \\
\hline 2. & $\begin{array}{l}\text { Explorative study of local } \\
\text { typical culture which can be } \\
\text { used to design a culture }\end{array}$ & $\mathrm{C}$ & 1 & $\begin{array}{l}\text { - Cultural studies will result in an artifact and } \\
\text { add design alternative or batik pattern with } \\
\text { local typical culture nuance }\end{array}$ \\
\hline 3. & $\begin{array}{l}\text { Establishing batik craftsman } \\
\text { association (Cooperative or } \\
\begin{array}{l}\text { Batik association) in each } \\
\text { district }\end{array}\end{array}$ & $\mathrm{D}$ & 2 & $\begin{array}{l}\text { - There is a medium to channel aspiration and } \\
\text { production fulfillment }\end{array}$ \\
\hline 4. & $\begin{array}{l}\text { Entering batik knowledge into } \\
\text { one of the extracurricular } \\
\text { activities (TK, SD, SMP, SMA) } \\
\text { (E) }\end{array}$ & $\mathrm{E}$ & 2 & $\begin{array}{l}\text { - Through introducing batik to the children will } \\
\text { enhance their understanding, loving and } \\
\text { innovative insight }\end{array}$ \\
\hline 5. & $\begin{array}{l}\text { Establishing a community of } \\
\text { local batik observer }\end{array}$ & K & 2 & $\begin{array}{l}\text { - The existence of community will trigger a } \\
\text { workshop, discussion, opinion acuity }\end{array}$ \\
\hline 6. & $\begin{array}{l}\text { Training on various production } \\
\text { technology methods for UKM } \\
\text { engaged in batik production }\end{array}$ & $\mathrm{L}$ & 2 & $\begin{array}{l}\text { - Technology training will enhance various } \\
\text { methods in batik production }\end{array}$ \\
\hline 7. & $\begin{array}{l}\text { Legal facility acquired for } \\
\text { competent UKM }\end{array}$ & G & 3 & $\begin{array}{l}\text { - Legal will enhance a sense of pride to the } \\
\text { achievement in a batik design development }\end{array}$ \\
\hline 8. & $\begin{array}{l}\text { Increasing trade volume by } \\
\text { actively participating in a } \\
\text { fashion show etc. }\end{array}$ & $\mathrm{H}$ & 3 & $\begin{array}{l}\text { - Being participated in various events of } \\
\text { exhibitions and fashion shows will increase } \\
\text { UKM insight and competition map of batik } \\
\text { design }\end{array}$ \\
\hline 9. & $\begin{array}{l}\text { Batik promotion at various } \\
\text { prestigious events (national and } \\
\text { international) }\end{array}$ & I & 3 & $\begin{array}{l}\text { - Through increasing, batik image at national } \\
\text { and international's eye will create the sense of } \\
\text { pride and market needs }\end{array}$ \\
\hline 10. & $\begin{array}{l}\text { Design development training } \\
\text { for UKM }\end{array}$ & B & 4 & $\begin{array}{l}\text { - Design training will enhance design ability } \\
\text { that will enhance the number of patterns and } \\
\text { legal of batik in a local area }\end{array}$ \\
\hline 11. & $\begin{array}{l}\text { Batik introduction since the } \\
\text { early childhood }\end{array}$ & $\mathrm{O}$ & 4 & $\begin{array}{l}\text { - Increasing children's love and like to the local } \\
\text { culture }\end{array}$ \\
\hline 12. & $\begin{array}{l}\text { Enlarge market by actively } \\
\text { participating in a marketing } \\
\text { partnership through cooperative } \\
\text { outlet etc }\end{array}$ & M & 5 & $\begin{array}{l}\text { - Getting involved in an outlet and product } \\
\text { brand will result in to be more known by } \\
\text { consumer } \\
\text { - Craftsman concentrates to the production and } \\
\text { design development }\end{array}$ \\
\hline
\end{tabular}




\section{CONCLUSION}

Based on SWOT analysis, the highest priority to do are Integrated technology will enhance production capacity to decrease product price and Cultural studies will result in an artifact and add design alternative or batik pattern with local typical culture nuance.

\section{REFERENCES}

Bungin, Burhan, (2005). Penelitian Kualitatif. Jakarta : Prenada Media Group.

Iwantono, S. 2011. Kiat Sukses Berwirausaha. Grasindo. Jakarta.

Juliandi, A., Irfan dan Manurung, S. (2014). Metodologi Penelitian Bisnis, Medan : UMSU Press.

Moleong, Lexy, J. (2005). Metodologi Penelitian Kualitatif. Bandung : PT Remaja Rosdakarya.

Rangkuti, F. 2006. Analisis SWOT Teknik Membedah Kasus Bisnis. PT Gramedia Pustaka Utama. Jakarta.

Sugiyono. (2014). Metode Penelitian Kuantitatif, Kualitatif, dan R\&D. Bandung: CV Afabeta.

Suhalim, S. 2015. Aplikasi Metode Analisis SWOT untuk Merumuskan Strategi Bersaing pada Pt Berkat Karya Lestari. Jurnal AGORA 3 (2): 392-399. 